\title{
Tolerance Of Intellectual Property Theft
}

Robert B. Settle, Salisbury University, USA

Kirsten A. Passyn, Salisbury University, USA

Memo Diriker, Salisbury University, USA

Gerard R. DiBartolo, Salisbury University, USA

\begin{abstract}
A survey of the public tested the proposition that the degree to which theft is tolerable or reprehensible is significantly determined by whether the owner/victim is or is not directly deprived by the theft. Respondents registered their degree of condemnation of theft of physical goods from an individual and from a company, as well as theft of physical property and of intellectual property by copying the content. The findings indicate that theft of physical, personal property is regarded as significantly more reprehensible than either theft of physical goods from a nonpersonal owner or theft of intellectual property by copying content.
\end{abstract}

Keywords: Copyright Infringement, Ethics, Intellectual Property, Piracy, Security, Theft

\section{INTRODUCTION}

\begin{abstract}
f you learned that a friend had gone into an acquaintance's home and stolen a piece of personal computer equipment valued at more than $\$ 200$, you would almost certainly be appalled at your friend's actions. But what if you learned your friend had gone into someone else's office and made a copy of a computer program worth the same amount for his own personal use? Even though the value of the theft is the same, if you are typical of the average individual, you would be far less alarmed at such behavior! Similarly, people who would be outraged to find a friend or coworker had stolen a CD or DVD from their home might hardly flinch on learning the same person had borrowed and made a copy of those media. For reasons this study seeks to identify, people appear to be much less concerned with theft of intellectual property than with that of physical property.
\end{abstract}

\section{BACKGROUND}

Differential attitudes toward theft of physical versus intellectual property become an increasingly serious problem as the latter become an ever greater share of the total economic value of production. "Intellectual capital's rising value in the production of wealth has been mirrored by its increasing vulnerability to crime" (Snyder \& Crescenzi, 2009). The cost of intellectual property theft in 2004 was estimated to be $\$ 250$ billion and climbing (Wright, 2004). Losses due to online piracy in the music and film industries alone are currently estimated to be in the tens of billions of dollars (Szuskin, et al., 2009). Software piracy has become a very serious problem as the result of computers' increasing role in the everyday life of the public (Aminmansour, 1996; Picard, 2004).

Traditional approaches to the prevention of theft are mainly to protect the goods and to catch and punish perpetrators, but these are increasingly difficult to accomplish in this digital age (Peace \& Thong, 2003). The facility with which digital information can be stored, communicated, and disseminated makes it exceedingly difficult to contain and protect. When physical property is stolen, its absence makes the theft far more readily noticed than when digital property is copied while the original data remains intact and appears untouched. Thus, detection of the crime and capture of the thief are no easy matter. Despite these limitations, producers of digital property are striving to develop and improve protective measures (Im \& Koen, 1990; Waterman, et al., 2007; Wright, 2004).

Awareness of the probability of detection and punishment have been shown to affect attitudes and behavior regarding theft of computer software by individuals (Moores, et al., 2009). In the music industry, income and risk perceptions, as well as personal ethics, are important determinants of willingness to pay when "free," pirated copies are available (Chen, et al., 2009; Chiang, E, \& Assane, D, 2009). There is also evidence that intellectual property 
theft may result purely because the perpetrators do not recognize copyright infringement of such intellectual property as training manuals and materials is illegal (Doherty, 2006).

Perhaps the study most relevant to this research sought to discover why people are so prone to steal software (Nunes, Hsee, \& Weber, 2004). It examined why typically law-abiding people are more inclined to steal intellectual property products than more tangible material products. The main thrust of that study was that consumers believe they cause less harm if their failure to pay prevents the owner of the property from recovering fixed, rather than variable cost; therefore, they feel less obligated and are less likely to pay voluntarily.

\section{RESEARCH QUESTIONS}

The thesis to be tested here is that people's reactions toward theft depend significantly on their perceptions of the degree of deprivation of a victim, rather than merely on the value of the item stolen. If an identifiable individual is personally, directly and immediately deprived by the theft, that appears to earn substantial condemnation. By contrast, if the individual in possession of the object that is stolen is not personally deprived by the theft - if that person is not a direct victim, others are likely to be significantly more tolerant of the thievery. The following propositions emerge:

- With the theft of physical property (e.g., a computer printer) the thief obtains the property and the owner is directly deprived of the property.

- With the theft of intellectual property (e.g., a computer program) the thief obtains a copy and the owner is not deprived of the property.

- Thus, theft of intellectual property is more acceptable or less reprehensible because there is no direct deprivation of the victim.

- The degree to which a theft is tolerable or reprehensible is significantly determined by whether the owner/victim is seen as deprived or not deprived by the theft.

When the object of a theft is some form of physical goods that are the personal property of an individual, that person is clearly an identifiable, personal victim. On the other hand, if the goods belong to a non-personal entity - a company, organization, or government unit-one or more individuals may be inconvenienced or temporarily deprived of the use of the object, but the precise victim is far less visible and identifiable. This leads to the first of two research hypotheses:

- To the degree that tolerance or condemnation of theft depends on the perceived effect on victims, respondents should regard theft from an individual as more reprehensible than that from a non-personal victim, (e.g., a company).

If the object in question is intellectual property, rather than physical property and the thief merely makes a copy rather than stealing the original, the owner is not deprived of the possession and use of the goods, whether the item is owned by an individual or by a company, organization, or government. Thus, the second research hypotheses:

- If tolerance or condemnation of theft depends on the perceived effect on victims, respondents should regard theft of intellectual property (by copying) as less reprehensible than theft of physical property.

\section{METHODOLOGY}

A survey questionnaire was designed to simultaneously test both hypotheses. Respondents also reported their status on several demographic categories.

\section{Questionnaire}

Testing the first hypotheses required comparison of reactions to thefts of various items of physical goods from either an individual person or from a non-personal entity, a company. Testing the second hypothesis involved a similar measurement with items with the same specified value, but this time reactions toward theft of a copy of intellectual property and toward theft of physical property owned by an individual were obtained for comparison. In each case, the format and content of the instructions to respondents, the items and rating scales were as closely comparable as possible. 
The first section of the questionnaire listed, in random order, 18 items of property. These were selected on a judgment basis by the research team from an extensive list of items commonly owned by consumers or companies. The items are identified in Table 2.

Six of the items were valued at $\$ 75,6$ at $\$ 150$, and the remaining 6 at $\$ 225$. Half of the items were listed as belonging to a company and the remaining half, to an individual. A 9-point scale with extremes labeled "None" and "Severe" was shown beside each item. The instructions at the top of the page were as follows:

- How much should someone be punished if caught taking each of the following things that don't belong to them from the owners identified below?

On each line below, circle the number 1 if you think they should not be punished at all, the number 9 if they should be punished very severely, or some number between 1 and 9 to show how much you think they should be punished.

The second section of the questionnaire also listed 18 randomly ordered items, similarly selected, and also valued at $\$ 75, \$ 150$, and $\$ 225$. Half of the items, shown in Table 03, identified physical property, while the remaining half were identified as a copy of intellectual property (e.g., computer program, music CD, etc.). The instructions were as follows:

- How much should someone be punished if caught taking each of the following things or duplicating copies of things that don't belong to them?

On each line below, circle the number 1 if you think they should not be punished at all, the number 9 if they should be punished very severely, or some number between 1 and 9 to show how much you think they should be punished.

Lastly, respondents reported their status on the demographic variables shown in Table 1.

Table 1: Demographic Distributions of the Responding Sample*

\begin{tabular}{|c|c|c|c|}
\hline Sex & Percent & Employment & Percent \\
\hline 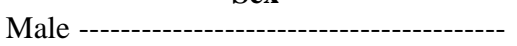 & 50.0 & Company Employed--- & 42.5 \\
\hline Female--------------------------------------- & 50.0 & Education, Government -- & 14.4 \\
\hline Marital Status & & Self-Employed ------------------ & 9.8 \\
\hline 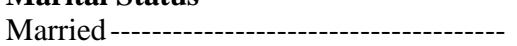 & 48.7 & Student - & 22.3 \\
\hline 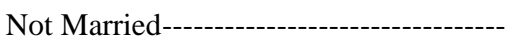 & 51.3 & Not Employed & 11.0 \\
\hline Adults in Home & & Occupation & \\
\hline One--1-- & 15.2 & Professional-- & 13.7 \\
\hline 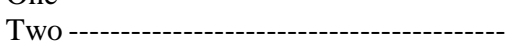 & 52.0 & Managerial, Technical --_-_-_-_-_- & 16.7 \\
\hline Three or More - & 32.8 & Admin., Clerical -- & 10.1 \\
\hline Children in Home & & Sales, Marketing --- & 8.9 \\
\hline None -------- & 65.0 & Skilled, Semi-Skilled --------------- & 11.9 \\
\hline 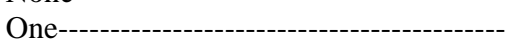 & 16.1 & Student -- & 22.3 \\
\hline Two --1-- & 12.2 & Not Employed or Reported -- & 16.4 \\
\hline Three or More - & 6.7 & Home Ownership & \\
\hline Age & & Owner -- & 63.7 \\
\hline Twenties---- & 33.5 & 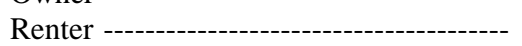 & 36.3 \\
\hline 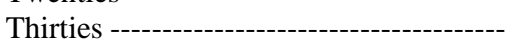 & 16.3 & Income & \\
\hline 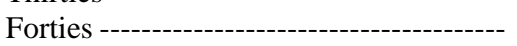 & 17.9 & Under 40,000 -- & 9.3 \\
\hline 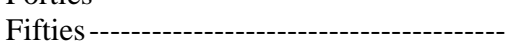 & 23.9 & 40,000 to 59,000 & 7.3 \\
\hline Sixties \& Over-- & 8.5 & 60,000 to 79,000 & 9.5 \\
\hline Education & & 80,000 to 99,000 & 7.9 \\
\hline High School Graduate & 28.1 & 100,000 to 139,000 & 12.9 \\
\hline Some College & 26.2 & 140,000 \& Over - & 17.9 \\
\hline College Graduate & 35.2 & 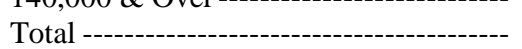 & 64.8 \\
\hline Post-Graduate & 10.5 & 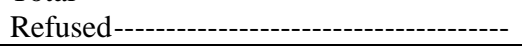 & 35.2 \\
\hline
\end{tabular}

$* \mathrm{~N}=1,273$ Respondents 


\section{Survey Procedures}

A convenience sample of 1.283 adult consumers from the general public in the Mid-Atlantic region was surveyed to obtain the data to test the research hypotheses. Respondents completed the self-administered questionnaire delivered to and retrieved from them by university student field workers, each assigned a quota of one man and one woman from each age decade from the twenties to sixties and over. The four-page questionnaire was accompanied by a cover letter explaining the nature of the project and seeking their participation.

Table 2: Mean Severity of Punishment Ratings by Item*

\begin{tabular}{|c|c|c|c|}
\hline \multicolumn{4}{|c|}{ Personal and Non-personal Victims } \\
\hline Value & Victim & Item Stolen & Mean \\
\hline \multirow{3}{*}{$\$ 75$} & \multirow{3}{*}{ Individual } & Leather Briefcase & 5.12 \\
\hline & & Jacket & 4.89 \\
\hline & & Kitchen Blender & 4.55 \\
\hline \multirow{3}{*}{$\$ 75$} & \multirow{3}{*}{ Company } & Desk Lamp & 4.36 \\
\hline & & Cordless Phone & 4.64 \\
\hline & & Power Drill & 4.97 \\
\hline \multirow{3}{*}{$\$ 150$} & \multirow{3}{*}{ Individual } & Barbecue Grill & 6.00 \\
\hline & & DVD Player & 5.82 \\
\hline & & Decorative Vase & 5.10 \\
\hline \multirow{3}{*}{$\$ 150$} & \multirow{3}{*}{ Company } & Set of Books & 5.03 \\
\hline & & Stereo Speakers & 5.58 \\
\hline & & Office Chair & 5.29 \\
\hline \multirow{3}{*}{$\$ 225$} & \multirow{3}{*}{ Individual } & Power Mower & 6.22 \\
\hline & & Lawn Furniture & 5.96 \\
\hline & & Wrist Watch & 6.20 \\
\hline \multirow{3}{*}{$\$ 225$} & \multirow{3}{*}{ Company } & Binoculars & 5.56 \\
\hline & & Portable TV & 6.18 \\
\hline & & Air Conditioner & 6.33 \\
\hline \multicolumn{4}{|c|}{ Intellectual and Physical Property } \\
\hline \multirow{3}{*}{$\$ 75$} & \multirow{3}{*}{ Intellectual } & Copy of Computer Game Program & 3.72 \\
\hline & & Copy Electronic of Music CD & 3.54 \\
\hline & & Copy of Electronic Mailing List & 5.02 \\
\hline \multirow{3}{*}{$\$ 75$} & \multirow{3}{*}{ Physical } & Computer Keyboard & 4.66 \\
\hline & & External Computer Hard Drive & 5.67 \\
\hline & & DVD Player & 5.12 \\
\hline \multirow{3}{*}{$\$ 150$} & \multirow{3}{*}{ Intellectual } & Copy of Set of House Plans & 5.25 \\
\hline & & Copy of Computer Graphics Program & 4.74 \\
\hline & & Copy of Documentary Video Program & 4.38 \\
\hline \multirow{3}{*}{$\$ 150$} & \multirow{3}{*}{ Physical } & Digital Camera & 5.95 \\
\hline & & Set of Mechanical Wrenches & 5.18 \\
\hline & & Oil Painting & 5.55 \\
\hline \multirow{3}{*}{$\$ 225$} & \multirow{3}{*}{ Intellectual } & Copy of DVD Video Training Program & 4.45 \\
\hline & & Copy of Computer Financial Program & 5.54 \\
\hline & & Copy of Technical Design Blueprints & 5.60 \\
\hline \multirow{3}{*}{$\$ 225$} & \multirow{3}{*}{ Physical } & Negotiable Financial Securities & 6.83 \\
\hline & & Flat Screen TV & 6.87 \\
\hline & & Portable Electric Air Compressor & 5.97 \\
\hline
\end{tabular}

*9-point scale, 1 = No Punishment, 9 = Severe Punishment

\section{RESULTS}

The demographic distributions of the responding sample, shown in Table 1, indicate there was a somewhat disproportionate number of young, well-educated singles, compared to other categories. Nonetheless, the sample does include a broad demographic spectrum of the adult population. 


\section{Individual Versus Company Victims}

The upper section of Table 2 contains the mean punishment severity ratings for physical property valued at $\$ 75, \$ 150$, and $\$ 225$ when the victims were either individuals or companies. These data were submitted to factorial analysis of variance to determine the significance of differences among mean values. The main effects of value, victim, item, and inter-subject differences, as well as all first-order interactions all proved to be statistically significant beyond the .0001 level of probability.

Table 3: Mean Ratings of Severity of Punishment (9-point scale)

\begin{tabular}{|lcccc|}
\hline \multicolumn{4}{c|}{ Value of the Property } \\
\hline Victim & $\mathbf{\$ 7 5}$ & $\mathbf{\$ 1 5 0}$ & $\mathbf{\$ 2 2 5}$ & All \\
\hline Individual & 4.85 & 5.64 & 6.13 & 5.54 \\
Company & 4.66 & 5.30 & 6.02 & 5.33 \\
Both & 4.76 & 5.47 & 6.08 & 5.43 \\
\hline Article & $\mathbf{\$ 7 5}$ & $\mathbf{\$ 1 5 0}$ & 6.56 & All \\
\hline Intellectual & 5.15 & 5.56 & 5.20 & 4.04 \\
Physical & 4.10 & 4.79 & 5.37 \\
Both & 4.06 & 4.67 & 5.40 & 4.71 \\
\hline
\end{tabular}

Figure 1: Mean Severity of Punishment Ratings

\begin{tabular}{|l|l|l|l|l|l|l|}
\hline \multicolumn{3}{|c|}{ Individual versus Company Victims } & \multicolumn{3}{|c|}{ Intellectual versus Physical Property } \\
\hline
\end{tabular}

\section{Intellectual Versus Physical Property}

The lower section of Table 2 displays the mean ratings for corresponding values of goods that are either intellectual or physical property. Factorial analysis of variance revealed that all main effects and first-order interactions were statistically significant beyond the .0001 level of probability.

\section{Combined Mean Ratings}

Mean ratings for each set of three corresponding items of the same value, representing personal versus nonpersonal victims and physical versus intellectual goods are summarized in Table 3 and depicted in Figure 1. The greater the specified value of the item, the higher the punishment severity ratings are in every case, as might be expected. For each value level, severity ratings for company-owned items are lower than those when the victim is an individual person. Similarly, severity of punishment ratings for theft of intellectual property were lower than for physical goods; however, the differences at all three value levels were markedly greater than for company versus individual property. 


\section{Demographic Effects}

An index composed of the differences between company versus personal property and intellectual versus physical property theft punishment ratings for each of the three price levels was computed. These mean values were submitted to analysis of variance for each of the demographic categories shown in Table 1 . The degree of distinction in condemnation of theft of company versus personal property and physical versus intellectual property proved to be virtually independent of the demographic status variables.

\section{CONCLUSIONS}

The results of this study provide substantial support for the proposition that there is an inverse relationship between tolerance of theft, on the one hand, and the degree of direct deprivation of a victim, on the other. Thus, the most reprehensive thefts are those of physical, personal property, and the greater the value of the goods, the greater the condemnation.

\section{Research Hypotheses}

This study was designed to test the proposition that the degree to which a theft is tolerable or reprehensible is significantly determined by whether the owner/victim is seen as deprived or not deprived by the theft. Thus, theft of intellectual property is more acceptable or less reprehensible because there is no direct deprivation of the victim.

The first research hypothesis stated that the degree of tolerance or condemnation of theft depends on the perceived effect on victims. Thus, respondents should rate theft from an individual as more reprehensible than that from a non-personal victim such as a company. The results revealed this to be the case, furnishing support for that hypothesis.

It follows, then, that if tolerance or condemnation of theft depends on the perceived effect on victims, respondents should regard theft by copying of intellectual property as less reprehensible than theft of physical property, where the victim is deprived of the stolen goods. The findings provide substantial support for this second hypothesis, as well.

\section{The Moral Issue}

It is axiomatic in the area of criminology that most people do not refrain from crime mainly because they fear detection or punishment. Rather, they do not commit crimes simply because they are not criminals. They do not steal because they are not thieves. It is a moral constraint, but this is only a partial explanation. It raises the question of what lies behind the moral restriction against theft. Aside from religious stricture, the most likely candidate is the individual's sense of empathy. One does not victimize another because one would not want to be victimized one's self.

If this is the case, this sense of empathy is particularly potent and prohibitive with regard to stealing the physical, personal property of another individual. The perpetrator knows full well that the victim has been deprived of whatever goods were stolen. There is no escaping the knowledge that the victim has been harmed in direct proportion to the value the owner places on the stolen property. But what of the case of intellectual property?

When a thief takes a copy of intellectual property, whether it is "pirated" software, digital music, copyrighted text, a patented design, or some other content, it is vastly more difficult to see who has been victimized. The remoteness of the individual or entity harmed enables the rationalization that nobody has been hurt. Even if there is an awareness of impropriety in the background, the actual victim and the dispossession are nebulous, at best.

\section{Intellectual Property Security}

Obviously, technical and legal protection against theft of intellectual property will always be necessary, just as it is necessary for the security of physical goods, but clearly, intellectual property is something of a special case. 
It is "slippery" in a way that physical goods can never be. Even when stolen by copying, the original is not gone, so detection is difficult and sometimes theft is almost entirely undetectable. Such difficulties do not suggest technical and legal protection should be reduced or abandon; rather, that they should be intensified to keep pace with the growing threats.

As a complement to technical and legal protection of intellectual property, public policy and educational programs could support the effort to create understanding of the harm that results from theft of intellectual property. Until there is as much personal guilt and public shame associated with stealing intellectual property as there is with theft of physical goods, there are likely to be many who continue to break the law by violating others' property rights.

Media in every form and those who compose and provide the content might do much in this regard. It is common, even in academic literature, to have authors refer to "pirating" software. It does not seem to create much condemnation. On the other had, most people would be outraged if someone "pirated" their cell phone or laptop! Until such tolerance of intellectual property theft is abandon in favor of vehement, open condemnation of it, the creator and owners of intellectual property, as well as society at large, are likely to continue to be victimized.

\section{AUTHOR INFORMATION}

Robert B. Settle a Professor of Marketing and a member of the Marketing Educators' Research Group (MERG) at the Franklin P. Perdue School of Business, Salisbury University, Salisbury Maryland, U.S.A. Dr. Settle earned his Ph.D. from the University of California, Los Angeles.

Kirsten A. Passyn is an Assistant Professor of Marketing and a member of the Marketing Educators' Research Group (MERG) at the Franklin P. Perdue School of Business, Salisbury University. Dr. Passyn's Ph.D. is from Pennsylvania State University.

Gerard R. DiBartolo is an Associate Professor of Marketing and a member of the Marketing Educators' Research Group (MERG) at the Franklin P. Perdue School of Business, Salisbury University. His D.B.A. is from George Washington University.

Memo Diriker is a Professor of the Practice of Business and Economic Development, Director of the Business, Economic, and Community Outreach Network (BEACON) and a member of the Marketing Educators' Research Group (MERG) at the Perdue School of Business, Salisbury University. His D.B.A. is from the University of Memphis.

\section{REFERENCES}

1. Aminmansour, A. (1996). Software piracy is theft. Civil Engineering, 66(6).

2. Chen, E, Pan, C, Pan, \& M. (2009). The Joint Moderating Impact of Moral Intensity and Moral Judgment on Consumer's Use Intention of Pirated Software. Journal of Business Ethics, 90(3).

3. Chiang, E, \& Assane, D. (2009). Estimating the Willingness to Pay for Digital Music. Contemporary Economic Policy, 27(4).

4. $\quad$ Doherty, W. (2006). Copyright theft. Industrial and Commercial Training, 38(7).

5. Im, J. H., \& Koen, C. M., Jr. (1990). Software Piracy and Responsibilities of Educational Institutions. Information and Management, 18(4).

6. Moores, T, Nill, A, Rothenberger, M. (2009). Knowledge of Software Piracy as an Antecedent to Reducing Pirating Behavior. The Journal of Computer Information Systems, 50(1).

7. Nunes, J. C., Hsee, C. K., \& Weber, E. U. (2004). Why Are People So Prone to Steal Software? The Effect of Cost Structure on Consumer Purchase and Payment Intentions. Journal of Public Policy and Marketing, 23(1).

8. Peace, A. G., \& Talletta, D, \& Thong, J. (2003). Software piracy in the workplace: A model and empirical test. Journal of Management Information Systems, 20(1). 
9. Picard, R. G. (2004). A Note on Economic Losses Due to Theft, Infringement, and Piracy of Protected Works. Journal of Media Economics, 17(3).

10. Snyder, H., \& Crescenzi, A. (2009). Intellectual capital and economic espionage: new crimes and new protections. Journal of Financial Crime, 16(3).

11. Szuskin, L, Fourques de Ruyter, S, Doucleff, \& J. (2009). Beyond Counterfeiting: The Expanding Battle Against Online Piracy. Intellectual Property \&amp; Technology Law Journal, 21(11).

12. Waterman, D, Wook Ji, S, Rochet, L. (2007). Enforcement and Control of Piracy, Copying, and Sharing in the Movie Industry. Review of Industrial Organization, 30(4).

13. Wright, B. (2004). The Staggering Cost of Copyright Theft. Broadcasting and Cable, 134(46).

\section{$\underline{\text { NOTES }}$}

